\title{
Suboptimal platelet response to clopidogrel after percutaneous coronary intervention in patients with acute coronary syndrome is not associated with total platelet count and mean platelet volume
}

\author{
Jure Samardžićc ", Miroslav Krpan', Marija Brestovac², Boško Skorić', Maja Čikeš', Mate Petričević', \\ Davor Miličić' \\ ${ }^{1}$ University of Zagreb School of Medicine, University Hospital Centre Zagreb, Zagreb, Croatia \\ ${ }^{2}$ Dr. Andrija Štampar Institute of Public Health, Zagreb, Croatia
}

Objectives: Responsiveness to clopidogrel is characterized by large variability in platelet inhibition among patients. ${ }^{1}$ Suboptimal response to clopidogrel is known to be associated with higher risk for subsequent cardiovascular ischaemic events such as in-stent thrombosis or recurrent acute coronary syndrome (ACS) ${ }^{2-3}$. We sought to evaluate correlation of platelet count and mean platelet volume (MPV) with low clopidogrel response in patients with acute coronary syndrome undergoing percutaneous coronary intervention (PCI).

Patients and Methods: We enrolled 359 consecutive ACS patients in the study. Patients with thrombocytopenia, suboptimal $\mathrm{PCl}$ and those who received glycoprotein IIbllla antagonists during and/or after $\mathrm{PCl}$ were excluded (120 patients). Residual platelet activity specific to clopidogrel was measured using Multiplate ${ }^{\circledast}$ function analyzer - a point of care instrument which determines platelet function in small quantities of whole blood.

Results: Fifty-three patients (22.2\%) had suboptimal response to clopidogrel. Average platelet number and MPV in patients with decreased response was $240.8 \times 10^{9} / \mathrm{L}$ (SD \pm
52.40) and $9.63 \mathrm{fL}(\mathrm{SD} \pm 1.00)$, respectively. Patients with normal or increased response had average platelet number of $226.6 \times 10^{\circ} / \mathrm{L}(\mathrm{SD} \pm 53.02)$ and average MPV $9.3 \mathrm{fL}(\mathrm{SD} \pm$ $0,91)$. There was no statistically significant difference in total platelet number $(P=0.07)$ nor MPV values $(P=0.13)$ between low responders and other patients.

Conclusion: MPV and total platelet number are not associated with low respond to clopidogrel after successful PCl in ACS.

KEYWORDS: acute coronary syndrome, clopidogrel, mean platelet volume.

CITATION: Cardiol Croat. 2013;8(9):279.

\section{Received: $28^{\text {th }}$ Jul 2013}

*Address for correspondence: Klinički bolnički centar Zagreb, Kišpatićeva 12, HR10000 Zagreb, Croatia.

Phone: +385-1-2367-467

E-mail: jure.samardzic@gmail.com

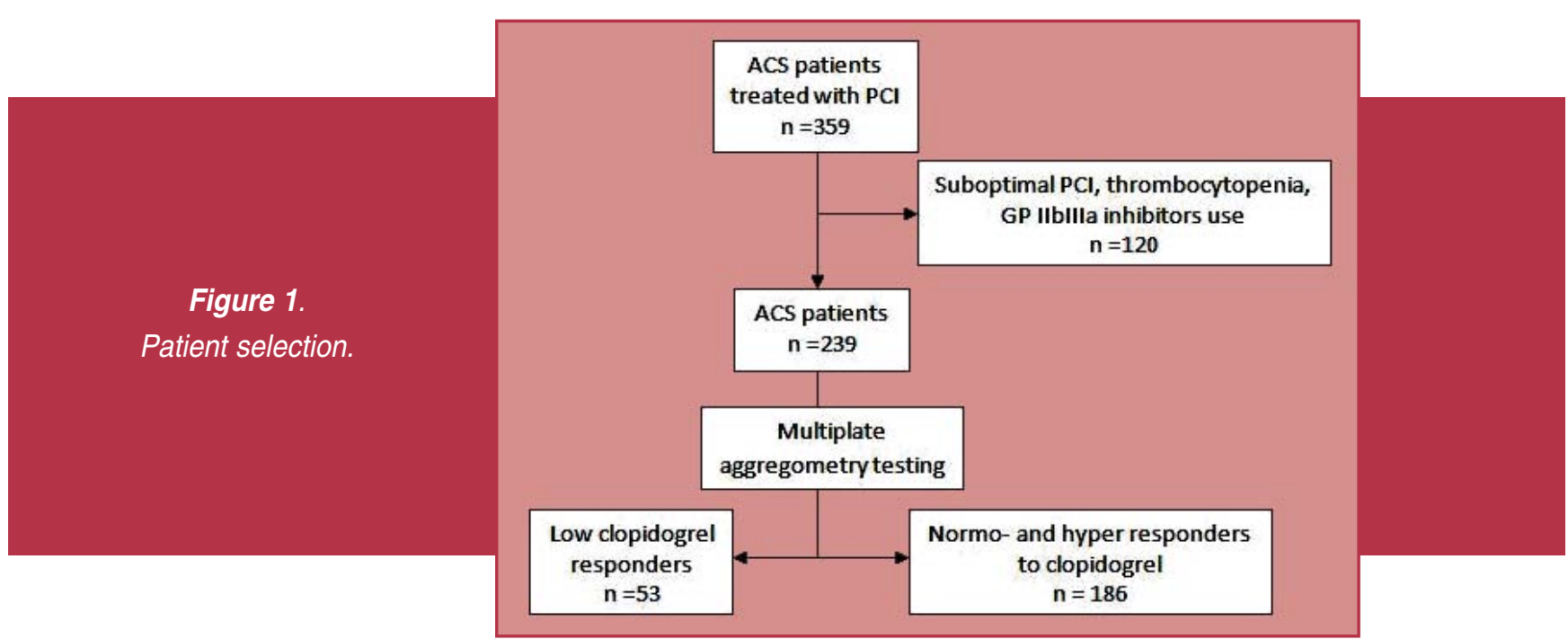

\section{Literature}

1. Angiolillo DJ, Fernandez-Ortiz A, Bernardo E, et al. Variability in individual responsiveness to clopidogrel: clinical implications, management, and future perspectives. J Am Coll Cardiol. 2007;49(14):1505-16.

2. Wenaweser $P$, Hess O. Stent thrombosis is associated with an impaired response to antiplatelet therapy. J Am Coll Cardiol. 2005;46(5):CS5-6.

3. Price MJ, Endemann S, Gollapudi RR, et al. Prognostic significance of post-clopidogrel platelet reactivity assessed by a point-of-care assay on thrombotic events after drug-eluting stent implantation. Eur Heart J. 2008;29(8):992-1000. 